\title{
IMPORTÂNCIA DA FOTOSENSIBILIZAÇÃO PARA A MEDICINA HUMANA E VETERINÁRIA (*)
}

POR

\author{
M. Rocha e Silva
}

(Do Instituto Biologico de S. Paulo)

Com 5 estampas

Os fenômenos de sensibilização de seres vivos à luz, produzidos por numerosos corantes fluorescentes, foram designados por TAPPEINER (1904) com o nome de "Ação fotodinâmica».

Doses de corantes, praticamente inócuas, no escuro, tornam-se extremamente tóxicas quando a sua ação se exerce em presença da luz. Paramécios, pequenos invertebrados, hemátias, tecidos isolados de vertebrados, postos em contacto com tais corantes, resistem à sua ação quasi indefinidamente, no escuro. Expostos entretanto à luz, por alguns minutos, observam-se graves fenômenos de morte e destruição celular. Em alguns minutos, os paramécios são destruidos, as hemátias hemolisadas, os tecidos vivos sofrem profundas alterações degenerativas. A injeção de tais corantes, em mamíferos, produz efeitos tóxicos graves, como edemas, dermatites, necroses da pele, estados de choque, exclusivamente quando os animais injetados são expostos à luz.

Embora o mecanismo da ação fotodinâmica seja ainda obscuro e objeto de contínuas investigações, é, sem dúvida, um fenômeno fotoquímico e portanto sujeito ao postulado enunciado há mais de um século por $T_{H}$. von Grothus (1817), segundo o qual «apenas as radições absorvidas pelo corante sensibilizante têm atividade fotoquímica». Efetivamente numerosas experiências demonstraram que o fenômeno fotodinâmico não se produz desde que sejam excluidas, do espectro luminoso incidente, as radiações absorvidas pelo corante. A experiência pode ser facilmente realizada com paramécios sensibilizados pela eosina. É o bastante interceptar a luz incidente, com um filtro formado por uma fina camada de eosina para que os paramécios continuem vivos dentro da solução do mesmo corante. Retirado o filtro entretanto, os paramécios são destruidos em poucos minutos. Experiência semelhante foi realizada por QuIN (1933) em carneiros sensibilizados pela eosina ou rose-bengala e expostos à luz. Desde que o pêlo fosse pincelado com o mesmo corante que serviu para a sensibilização, os carneiros mostravam-se protegidos contra os efeitos irritantes da luz solar.

(") Comunicado à Soc. Biologia S. Paulo em 8-4-1940. 
Os efeitos graves produzidos em vertebrados pela injeção de corantes fluorescentes e subsequente exposição à luz, provém sem dúvida da enorme permeabilidade da pele aos raios visíveis do espectro, justamente aqueles que são ativos, na produção do fenômeno. E tão grande a permeabilidade da pele de mamíferos a tais radiações, que TAPPEINER (1904) conseguiu destruir paramécios sensibilizados pela eosina, fazendo incidir sôbre êles a luz que filtrou através de fina camada de pele. Haussmann (1919) obteve hemólise, pela irradiação de eritrocitos sensibilizados pela eritrosina, através de uma orelha de coelho.

Acidentes produzidos pela injestão ou injeção de corantes fluorescentes, para fins terapêuticos e subsequente exposição à luz do sol, têm sido frequentemente referidos na literatura. De regra, desenvolve-se uma dermatite mais ou menos grave, na maioria das vezes do tipo urticariforme. Os primeiros casos bem estudados foram os de PrIME, em indivíduos aos quais foi administrada eosina em combinação com brometos, no tratamento da epilepsia. As doses de eosina administradas em 26 casos de epilepsia, foram as seguintes: $0,25 \mathrm{gm}$. per os, no começo, atingindo na 7.a semana 2,5 gms. por dia, e na nona semana 3,5 gms, por dia e per os.

Quando a dose atingia 2,5 gms. a 3 gms. por dia, o rosto e as mãos apresentavam coloração vermelha pelo acúmulo do corante. Um edema indolor sucedia. Em seguida, as regiões mais impregnadas de corante mostravam ulcerações, de preferência nas zonas que apresentavam pequenos ferimentos. Sob as unhas apareciam lesões que progrediam da periferia para a matriz. Essas lesões, de regra necróticas, se mostravam de preferência na unha do polegar, provavelmente porque êsse dedo é habitualmente mais exposto à luz. O aparecimento de lesões nas zonas que previamente apresentavam ferim ntos, segundo JOOLBAUER, seria consequência de um acúmulo maior de corante nesses pontos.

As observações de PrIme, bem como a experiência pessoal de Meyer-Betz (1913) são as primeiras descrições de fotosensibilização no homem. Meyer-Betz injetou $0,2 \mathrm{gm}$. de hematoporfirina na própria veia e apresentou sintomas severos de sensibilização à luz. Desenvolveram-se edemas sub-cutâneos graves e destruições localizadas da pele.

JaUSion \& MARCERON (1925) descreveram o que designaram como coup de lumière acridinique. Nove de 20 soldados tratados com tripaflavina (derivado da acridina) apresentaram sintomas graves pela exposição ao sol. Outros pesquisadores descreveram dermatites e pigmentação exagerada em indivíduos tratados com derivados da acridina. 
Blum (1933) refere um caso de hipersensibilidade à luz em indivíduo que recebeu injeção de rose-bengala para prova funcional do fígado. Acidentes foram observados nas experiências de Gyorgi \& GotTlieb (1923) e Strauch (1930) que procuraram tratar o raquitismo pela injeção de corantes fluorescentes e subsequente irradiação, baseados na analogia apenas aparente entre os efeitos dêstes últimos e os efeitos produzidos pelos ráios ultra-violeta. Uma sequela do tratamento da melancolia com o cloridrato de hematoporfirina (Photodyn) foi recentemente descrita por Blum \& Templeton (1937). Consistia em severa urticária seguida de intensa pigmentação da pele, resultante da exposição à luz, mesmo dois meses depois do uso da droga.

Antes de estudarmos as esperiências realizadas em animais de laboratório, citaremos ainda uma experiência involuntária realizada na Alemanha no comêço dêste século, em porcos, graças à ignorância do govêrno dos fenômenos acima referidos e que nos foi relatada pelo prof. H. Embden. Para distinguir a cevada destinada à alimentação de suinos, da cevada destinada á alimentação humana, submetida a pesados impostos alfandegários, foi imposta uma lei que exigia que a cevada destinada aos animais fosse misturada com eosina. Os porcos adquirindo a coloração da eosina (Eosinschwein) apresentavam aspecto bizarro. Lesões graves da pele e acidentes diversos assinalados em tais porcos, determinaram o abandono da lei.

\section{EXPERIÊNCIAS EM PEQUENOS MAMÍFEROS}

Embora a pele, como mais exposta às irradiações seja a mais atingida pela ação fotodinâmica in vivo, as lesões da pele extensas e graves, repercutem sôbre os órgãos internos produzindo acidentes frequentemente mortais. SMETANa (1928) estudou o choque circulatório produzido em gatos pela injeção de hematoporfirina na veia e exposição à luz. Observou queda da pressão arterial ao nivel de choque e perturbações respiratórias graves. A morte ocorria ao fim de algumas horas de exposição à luz. Haussmann (1914) descreveu o seguinte grupo de sintomas em camondongos albinos sensibilizados pela hematoporfirina :

1. ${ }^{\circ}$ Forma super-aguda: os animais caem em coma dentro de alguns minutos e morrem pouco tempo depois.

$\left.2 .^{\circ}\right)$ Forma aguda: os animais mostram sinais de grande agitação, aparecem edemas na face e sinais de fotofobia; a morte ocorre em algumas horas.

3. ${ }^{\circ}$ Forma crônica: caracterizada pelo aparecimento de lesões necróticas nas partes mais expostas da pele, os pêlos caem em tôrno dos olhos, as orelhas necrotizadas podem cair completamente. 
Buengeler (1937) realizou experiências em camondongos sensibilizados com eosina, hematoporfirina e alcatrão. As lesões inflamatórias que aparecem em seguida às primeiras horas de irradiação, são assim descritas: "O primeiro e mais grave sintoma que aparece já depois da primeira irradiação, é uma conjuntivite com blefaroespasmo. Segue-se um eritema de toda a pele, especialmente da orelha, dos pés e da cauda. Mais tarde eczema com formação de bolhas e úlceras das partes glabras da pele. No estadio de eritema difuso da pele e do comêço do eczema, morrem muitos animais, sendo justamente nesta fase da experiência que as perdas são maiores. Os animais morrem habitualmente depois de um período prévio de excitação, apresentando convulsões tetânicas e fenômenos de paralisia das extremidades posteriores. Anatomicamente ao lado das lesões da pele, hiperemias fortes dos orgãos abdominais, hemorragias nas serosas e mucosas puderam ser observadas. BUENGeler refere ainda a produção de úlceras pépticas no estômago e a maior incidência de tumores como sequelas do tratamento combinado daquelas substâncias fluorescentes e luz solar direta.

As experiências ilustradas pelas figuras 1-7, foram por nós realizadas em coelho pela injeção de rose bengala, na veia. Duas horas de irradiação ao sol, foram suficientes para fazer aparecer durante os dias subsequentes, extensas e graves lesões na região depilada da pele, 24 a 48 horas depois da irradiação, manifestou-se extenso edema sub-cutâneo, com reações inflamatórias conjuntivais. Ao fim de 1 semana podiam-se ver extensas lesões necróticas de toda a região da pele mais atingida pela luz. Tromboses dos vasos superficiais, extensas quedas de pêlo, sobretudo em tôrno do olho, mumificação da orelha seguida de queda, de pelo menos $2 / 3$ do pavilhão, foram outras tantas lesões que puderam ser observadas.

\section{HIPERICISMO}

Desde meados do século passado eram atribuidos à luz, acidentes graves produzidos em certas regiões da Europa pela planta Hypericum crispum. Heusinger (1846) já atribuiu à luz o desencadeiamento da doença, designada como hipericismo, já conhecida de uma literatura antiga italiana. A doença desenvolve-se sobretudo em carneiros: "a lã cái, a cabeça incha e os carneiros morrem ao fim de 3 semanas». E' sabido que só os carneiros brancos são atingidos, daí o fato de que no Tarentino onde a planta existe, são creados de preferência carneiros pretos. Observações em equinos foram feitas por 
PANGOUÉ (1861) que atribuiu à luz os acidentes graves registrados em animais alimentados com feno de Hypericum perforatum (ST. JoHannis KRAUT).

Em 1914, Ray publicou um relatório detalhado dos efeitos tóxicos produzidos pelo Hypericum crispum que cresce abundantemente em Tunis, sendo conhecido dos árabes com o nome de Hamra. Carneiros, cabras, bois e cavalos podem sofrer os efeitos da injestão da planta. Êsses efeitos tóxicos só aparecem à luz e nos animais não pigmentados. Os sintomas iniciais são: imobilidade, cabeça pendente, eritema e edema das áreas não protegidas da pele. Nos carneiros, cabras e bois, especialmente as orelhas e pálpebras são atacadas, mostrando-se enormemente inchadas. Se os animais são protegidos da luz, não são atacados pela planta. Os árabes coram a pele dos cavalos brancos com hena e tabaco, com o fim de protege-los da luz.

Em 1922, Henry fez experiências de alimentação de bois e carneiros produzindo sintomas típicos de envenenamento pelo Hypericum perforatum e mostrou que outras espécies como Hypericum maculatum e Hypericum pulchrum são igualmente venenosas. MAYER (1926) refere acidentes em cavalos alimentados com Hypericum perforatum e assim descreve os sintomas: «As primeiras manifestações mórbidas aparecem no lábio superior quando branco, que se mostra logo edemaciado. O toque da parte edemaciada e febril é muito doloroso para o animal».

Mais recentemente MARSH \& CLAwSON (1928) realizaram um trabalho experimental exaustivo de alimentação intensiva de 31 bois e 33 carneiros com o Hypericum punctatum (ST. JoHN's WORT). Dos 31 bois alimentados com Hypericum um único morreu apresentando todos os sintomas típicos de uma fotosensibilização. 3 dias depois da administração da planta em quantidade correspondente a $5 \%$ do pêso, o animal apresentava respiração acelerada, cêrca de 160 por minuto. $\mathrm{O}$ animal mostrava-se ofegante (panting), a temperatura subiu rapidamente a $106,8^{\circ} \mathrm{F}$., o pulso a 84 e 90 por minuto. A morte ocorreu 4 dias depois da administração da planta. A autópsia mostrou hemorragias petequiais nos ventrículos cardíacos, edema pulmonar discreto, degeneração das células hepáticas e dilatação da vesícula biliar. Não havia entretanto nenhuma anomalia séria e típica nos órgãos do animal morto pela alimentação com o Hypericum punctatum. Dos outros 30 bois, 20 foram nitidamente atingidos pela planta, mostrando de regra respiração acelerada e panting. Em 6 casos, houve elevação de temperatura e em 12, pulso acelerado. Diarréia mais ou menos grave foi observada em 14 casos. Em alguns casos foram observadas dermatites, aliás benignas. Dessas experiências, os autores norte-ame- 
ricanos concluem que embora tóxica, os efeitos venenosos da planta não são muito pronunciados, o que estaria em contradição com os resultados de outros autores que assinalaram o Hipericismo como um serio perigo para a criação.

Ora, êste resultado é de grande importância na interpretação dos efeitos produzidos por outras plantas que produzem acidentes de fotosensibilização, com um índice de mortalidade muito elevado. $O$ Geeldikkop por exemplo, que estudaremos a seguir, pode matar $60 \%$ dos animais atingidos. As lesões no fígado são muito pronunciadas e a iterícia impressionante. Os acidentes mortais produzidos aquí no Estado de São Paulo pelo Holocalyx glaziovii (Alecrim) atingem igualmente grande porcentagem dos animais que comem a planta. Num pasto de 10 alqueires na fazenda Guanabara, onde havia 40 bois, cêrca de 17 morreram nos primeiros 15 dias de desencadeiada a moléstia. Os outros salvaram-se, provavelmente por terem sido retirados do pasto, a tempo.

As plantas do grupo Hypericum contêm um pigmento fluorescente, assinalado pela primeira vez por Cerny (1911). Haussmann \& ZARIBNICKY (1929) mostraram que uma substância, intensamente fluorescente, extraida do Hypericum perforatum, produz hemólise fotodinâmica. IonNiDẻs (1930), descreveu um método de purificação do pigmento foto-tóxico extraido do Hypericum crispum: a injeção dêsse produto purificado sensibilizou ratos brancos à luz. Assim o Hipericismo parece ser uma doença produzida por uma planta não tóxica, mas contendo um pigmento fluorescente que torna o animal sensivel à luz. Os resultados a esperar com a alimentação intensiva com a planta, seriam do mesmo tipo dos resultados obtidos pela injeção de corantes fluorescentes, como a hematoporfirina, eosina ou rose-bengala. Veremos adiante, que das experiências de Quin $(1931,33)$ pode-se concluir que a simples fotosensibilização por corantes fluorescentes não é suficiente para explicar a forte iterícia observada no Geeldikkop.

\section{FAGOPIRISMO}

Em certas regiões da Europa teve sempre importância o complexo mórbido desde muito conhecido como fago pirismo. Animais alimentados exclusivamente com o trigo sarraceno (Polygonum fagopyrum) apresentam sintomas sérios de sensibilização à luz.

Os animais mostram sinais de grande agitação, edemas extensos sub-cutâneos, eritemas e erupções da pele, prurido. Nas formas extremas a morte sobrevem em poucos dias. A evidência de que em 
tais casos se trata de uma fotosensibilização, é dada pelos seguintes fatos: $10^{\circ}$ ) Animais alimentados com o trigo sarraceno, mas mantidos em cocheiras e estábulos não apresentam os sintomas. 2. ${ }^{\circ}$ ) Animais retirados do sól logo que os primeiros sintomas desencadeiam, recuperam rapidamente. $3 .^{\circ}$ ) As áreas não pigmentadas da pele são as mais facilmente atingidas, os animais claros sendo mais atingidos que os escuros.

Em 1928, SHEARD \& Col. fizeram um estudo detalhado da fotosensibilização de animais de laboratório alimentados durante muitos dias com o Polygonum fagopyrum. Particularmente cobáias puderam ser sensibilizadas de maneira intensa pela alimentação exclusiva com a planta fresca. Porcos brancos e cabras mostraram sintomas nítidos de fotosensibilização, embora menos intensos que os desencadeiados em cobáias. SHEARD \& Col. assim descrevem os sintomas e exames post-mortem: "As modificações anatômicas notadas em casos de envenenamento pelo trigo sarraceno variam de acôrdo com a duração e intensidade da exposição dos animais sensibilizados. Depois de curta exposição (20 minutos) à luz solar, as modificações histológicas mais importantes são: hiperemia da pele e edema. Reações mais severas mostram edemas, bolhas e mesmo ulcerações. Uma forma mais grave é acompanhada de hemorragias do tecido conjuntivo sub-cutâneo, seguidas da formação de crostas. Reações fatais mostram as alterações já citadas da pele e tecido conjuntivo sub-cutâneo e mais, hemorragias petequiais dos pulmões, cérebro, fígado, estômago e rins. Degenerações parenquimatosas puderam ser observadas. O que mais impressiona nos exames post-mortem de animais fotosensibilizados e mortos pela exposição à luz, é a falta de qualquer alteração patológica típica. As lesões encontradas sugerem a existência de profunda toxemia. Nos animais submetidos a reações severas, um aumento nítido da coagulabilidade do sangue foi observado. E' difícil retirar sangue dêsses animais. Exames post-mortem mostram frequentemente coágulos nos grandes vasos».

De acôrdo com TAPPEINER (1909) o princípio ativo da fotosensibilização produzida pelo trigo sarraceno, é uma substância alcool soluvel do tipo da clorofila. Busch (1905) atribuiu os efeitos do trigo sarraceno a um pigmento nele existente - a fluorofila. Depois de uma série de ensaios espectrográficos, SHEARD \& Col. (1928) admitiram a possibilidade de um derivado da clorofila, a filoeritrina, ser o agente responsavel pela fotosensibilização produzida pelo trigo sarraceno. 


\section{O PROBLEMA DO GEELDIKKOP}

Uma outra doença estudada de maneira exaustiva na Africa do Sul, é a chamada Tribulose ovina. Assinalada pela primeira vez por HutCHEON em 1886, a doença é habitualmente designada como Geeldikkop (cabeça inchada e amarela) pelos fazendeiros.

Em determinadas épocas do ano uma planta que normalmente constitue excelente forragem para os carneiros, o Tribulus terrestris, se torna a causa primária do complexo mórbido designado como Tribulose ovina, caracterizado por iterícia profunda, lesões necróticas do fígado que se mostra amarelo-ouro, extensos edemas sub-cutâneos localizados sobretudo na cabeça e nas pernas, finalmente necroses da pele com formação de escaras.

Em 1918, THEILLER apresentou estudo detalhado da doença, admitindo pela primeira vez que uma parte do quadro mórbido poderia ser explicado por uma sensibilização à luz, porquanto os animais mostram sinais intensos de agitação, fotofobia e as lesões cutâneas se desenvolvem sobretudo nas áreas não pigmentadas e mais expostas da pele. O estudo clínico e anatomo-patológico de numerosos casos observados por THEILLER pode ser resumido da seguinte maneira: $\mathrm{Na}$ fase aguda da doença, o animal apresenta edemas extensos sub-cutâneos, originados inicialmente pela infiltração de um líquido claro que se cora posteriormente de amarelo carregado. Nos casos de evolução mais lenta, depois dos edemas sub-cutâneos, sucede-se uma fase de lesões necróticas da pele, sobretudo da face, das orelhas e do focinho. Formam-se extensas escaras, fortemente coradas de amarelo na parte interna. Queratites mais ou menos graves são observadas, acompanhadas algumas vezes de ulcerações da córnea. A pele em tôrno dos olhos frequentemente se mostra necrosada, com formação de escaras. A autópsia mostra o fígado intensamente corado de amarelo, grande dilatação da vesícula biliar, bile ligeiramente viscosa, embora sempre verde. Fascias e aponevroses intensamente coradas de amarelo. A incisão do edema sub-cutâneo determina a exsudação de um líquido amarelo-ouro. Ao exame microscópico, o fígado mostra células carregadas de pigmento amarelo ou pardo, frequentemente necróticas, sem depósito de gordura.

A ordem de sucessão dos sintomas é de grande interêsse para o conhecimento do mecanismo de produção dos mesmos. A doença desencadeia de regra, com um surto febril e sinais de grande excitação do animal, que se mostra inquieto, sem apetite, deitando-se e levantando-se sucessivamente. Já nos primeiros dias, os edemas da face se tornam aparentes no lábio superior, no focinho e em seguida nas orelhas. Logo depois toda a cabeça se mostra edemaciada, os lábios 
espessados e rígidos. $\mathrm{O}$ animal sacode frequentemente a cabeça e coça o focinho. Os edemas são dolorosos à palpação e quentes. Os edemas aumentam rapidamente, durante os 4 primeiros dias, em seguida começam a diminuir e chegam a desaparecer completamente ao fim de uma semana. ( $\mathrm{Na}$ fase dos edemas o aspecto externo do animal não se distingue do aspecto apresentado pelo carneiro da fig. 9 injetado com hematoporfirina). Desaparecidos os edemas, a pele começa a se mostrar ressecada e endurecida, necrosada em extensas regiões, com formação de escaras que facilmente podem ser destacadas. As orelhas e os lábios são particularmente atacados, mostrando-se geralmente secos e inflexíveis. (Nesta fase o aspecto da cabeça do animal é semelhante à do carneiro da Fig. 10). O exsudato dos edemas inicialmente é claro, posteriormente amarelo intenso. A época de aparecimento da iterícia corresponde à segunda fase da moléstia, do $4 .^{\circ}$ ao 6.0 dia, coincidindo com o acmé da elevação de temperatura. Nessa fase a anorexia é quasi absoluta, o animal mostrando-se magro, com aspecto miseravel.

Foi possivel associar de maneira definitiva a moléstia à injestão de Tribulus terrestris. Embora uma única vez tenha sido reproduzida experimentalmente a doença, pela injestão da planta, a doença ocorre em campos de Tribulus em floração.

A reprodução experimental da doença depende de condições climatéricas especialíssimas, do estado da planta e de outras condições difíceis de precisar. THeILler (1918) que foi o único a obter resultados positivos com a injestão da planta, assim se exprime: whilst the feeding with Tribulus terrestris was undertaken the weather conditions for the evolution of Geeldikkop according to the experiments of the farmers had been ideal. Previous to the feeding there had been a rain lasting for three days which soaked the country thoroughly and which according to the experience of the farmers was one exceptional one for that part of the country. It was succeeded by hot sunny weather which was only once interrupted on the seventh day of experiment by rain. Tribulus terrestris the presence of which was noted at the time, suddenly sprang up luxuriantly after the rain and what before had been a dry karroo veld, changed into a luxuriant pasture, the flowering plants giving the verdure a yellow tinge. Nessas condições a planta, administrada imediatamente depois de colhida, reproduziu a doença em cêrca de $60 \%$ dos carneiros alimentados, o que levou THEILLER a concluir: The result of the experiment is thus clear and establishes the fact that Tribulus terrestris is the cause of Geeldikkop when fed exclusively to sheep whilst it is green flowering and at a time the weather is hot. It is howe- 
ver interesting to note that all feeding experiments undertaken subsequently gave negative results, although they were carried out under identical circumstances.

Outras experiências de alimentação intensiva de carneiros com Tribulus terrestris foram realizadas por QUIN (1930) com resultados completamente negativos. Pode-se concluir assim que Tribulus terrestris não é uma planta tóxica no sentido habitual. Em certa época do ano, em condições climatéricas e de floração muito especiais, animais alimentados exclusivamente com o Tribulus, desenvolvem a sintomatologia de Geeldikkop.

A importância de um fator externo, a luz solar, na produção dêsses sintomas, admitida inicialmente por THEILLER, foi tornada muito provavel pelos numerosos trabalhos de QUiN (1931 e 33) e QuiN \& Rimington (1933-37).

Inicialmente QUIN (1931) mostrou que carneiros e cabras injetados com hematoporfirina desenvolvem a sintomatologia externa do Geeldikkop. Os edemas e as lesões necróticas da pele são confinadas às partes expostas, cabeça, orelha e algumas vezes às pernas. Carneiros pretos nenhuma lesão apresentam e os carneiros que apresentam certas regiões da pele não pigmentadas desenvolvem lesões cutâneas localizadas justamente sôbre tais regiões. Posteriormente QuIN (1933) reproduziu sintomas típicos da doença injetando outros corantes fotosensibilizantes, como eosina, eritrosina, rose-bengala e azul de metileno, bem como pela ingestão de plantas sabidamente fotosensibilizantes, como Hypericum ethiopicum, glaucensis, etc. (Sôbre as experiências de Quin, ver figs. 8-11).

O passo seguinte foi dado pelas observações de Quin \& RIMINGTON (1934) que verificavam um aumento nítido, na bile dos animais mortos de Geeldikkop, de um pigmento fluorescente, derivado da clorofila a filoeritrina. Êsse pigmento, produto normal do metabolismo da clorofila, encontrado normalmente em pequenas quantidade no estômago de ruminantes (Rothemund \& INMAN, 1932; Quin, Rimington \& Roets, 1935) e na bile, acumula-se no organismo produzindo os acidentes graves, típicos do Geeldikkop, desde que haja retenção biliar. Fenômenos de fotosensibilização foram observados pela simples ligadura do colédoco (Quin, 1933). Em última análise, pode-se admitir que uma iterícia de retenção em herbívoros deve ser acompanhada de fenômenos secundários de fotosensibilização, porquanto perturbada a excreção daquele pigmento fluorescente e fototóxico os tecidos do animal se impregnam do mesmo. Efetivamente foi observado por Quin (1933) que uma planta da família das verbenáceas 
(Lippia rehmanni) produz uma iterícia em carneiros, muito semelhante à que ocorre no Geeldikkop. A planta produz um distúrbio hepático, seguido de iterícia de retenção (teste de Van den Bergh positivo no sangue) e fenômenos secundários de fotosensibilização à luz. Posteriormente Rimington \& Quin (1935) e Rimington, Quin \& Roets (1937) isolaram o princípio tóxico iterógeno contido em Lippia rehmanni. Essa substância cristalina, designada como iterogenina, age aparentemente produzindo uma atonia da vesícula biliar com forte estase de bile. A administração de pequenas doses da substância iterogenética, em carneiros, é seguida antes de 24 horas de fenômenos nítidos de fotosensibilização. $O$ animal se mostra inquieto, sem apetite, procurando sombra. Aparecem edemas das partes expostas, como face, orelhas e lábios, algumas horas depois, 4 a 5 dias depois necroses da pele podem ser observadas. A iterogenina é substância altamente tóxica, produzindo choque mortal na dose de $1 \mathrm{gm}$, por injeção na veia. Embora as experiências citadas acima constituam apenas modelos do Geeldikkop, pode-se admitir que a doença no campo tenha a sua origem numa iterícia de retenção e fenômenos de fotosensibilização consequentes à impregnação do organismo por aquele pigmento sensibilizante - a filoeritrina.

\section{FENOMENOS DE FOTOSENSIBILIZAÇÃO PRODUZIDOS PELO "HOLOCALYX GLAZIOVII" (ALECRIM)}

Ha 5 ou 6 anos atrás intensa epizootia foi assignalada no extremo noroeste do Estado de São Paulo, na Fazenda Guanabara, situada entre Andradina, Ilha Sêca e Lussanvira. A importância econômica consideravel da doença pode ser traduzida em números, porquanto segundo estimativas grosseiras, cêrca de 1.000 bois foram ceifados pela doença, sendo que só em 1938, cêrca de 300 bois foram vitimados.

A fazenda Guanabara foi aberta na floresta virgem e de 1932 para cá anualmente novos pastos são abertos pelo processo das queimadas. O método é sempre o mesmo e consiste em delimitar na floresta virgem, por meio de grandes picadas, uma certa área de algumas dezenas de alqueires. Dentro dessa área, as árvores são abatidas a machado, no fim do outono ou comêço do inverno. Em Agosto o fogo é ateado aos ramos secos e toda a vegetação é destruida pelas chamas. O terreno é em seguida sumariamente limpo, retirados os troncos caidos e não queimados e o capim é então semeado ou plantado naquele terreno ainda parcialmente coberto de cinzas. Depois das primeiras chuvas fracas de Agosto e Setembro, os tocos das árvores cortadas brotam de maneira exuberante e o pasto apresenta um 
aspecto sui generis: o capim ainda muito rasteiro, ou completamente sêco, constitue uma parte insignificante do pasto que é quasi todo constituido de brotos verdes ou avermelhados dos troncos de árvores cujas raizes não foram atingidas pelo fogo. Mais tarde, depois das chuvas de Novembro e Dezembro, o pasto se transforma, o capim se desenvolve de maneira espantosa, envolvendo aqueles troncos que desaparecem debaixo de um capinzal que pode cobrir um boi.

Justamente depois das primeiras chuvas de Agosto ou Setembro, os primeiros casos da terrivel doença começam a aparecer, de preferência nos pastos mais recentes. No ano passado (1939) em que a sêca se prolongou até comêço de Outubro, foi só na primeira quinzena dêsse mês que a doença se implantou de maneira mortífera, num único pasto de 10 alqueires abertos naquele ano (Figs. 12 e 13).

Os animais se mostram de início irritados, afastam-se do bando, agridem as pessôas. Continuamente abanam a cabeça. Nessa primeira fase frequentemente mostram extensos edemas nas orelhas e barbela frequentemente nas axilas e ao nivel do manúbrio external (Fig. 15). Se não morrem nessa fase aguda, convalescem lentamente, sempre com um aspecto miseravel. 10 a 12 dias depois da fase aguda, começam a apresentar necroses secas da pele com descamação e formação de escaras extensas. Nos casos fatais ou sacrificados na fase aguda, intensa iterícia é sempre encontrada na autópsia e ainda hemorragias localizadas ora no estomago e intestino, ora em todo o peritónio e pericárdio, frequentemente no tecido peri-renal. Hemorragias graves no tecido sub-cutâneo podem ser encontradas. O fígado apresenta-se amarelo e com degeneração gordurosa pronunciada. A vesícula biliar distendida contém uma bile espessa, muitas vezes semi-sólida, com o aspecto de geléia de morango. Os tecidos estão fortemente impregnados de pigmento amarelo. A incisão dos edemas sub-cutâneos faz escorrer uma serosidade côr de canário. Êsse exsudato coagula-se rapidamente. As lesões da pele se localizam de preferência nas partes claras e mais expostas da pele: Dorso e regiões laterais do tronco, barbela, axilas (na parte externa) e nas pernas, onde a pele é fina e quasi glabra. Muitas vezes toda a pele das partes laterais do tronco, se mostra ressecada, quebradiça, como casca de árvore (Figs. 17 e 18). De regra as orelhas são atingidas em primeiro lugar, mostrando-se inicialmente espessadas e depois ressecadas e quebradiças. Lesões nos olhos como panoftalmos, lacrimejamento intenso e conjuntivites purulentas, foram observadas em alguns casos (Fig. 16). Hipertermia, forte polipnéia e sinais de fotofobia foram observados por nós numa das viagens que fizemos à fazenda Guanabara. 
Os sintomas externos da doença sugerem fortemente a participação de um fator externo, no caso, a luz solar, dada a semelhança com as reações descritas como características da fotosensibilização. O alto índice de mortalidade verificado nos pastos onde se observou a moléstia, bem como as hemorragias localizadas no estômago e parte alta do intestino, levou-nos à convicção de que se tratava da ação de uma planta muito tóxica.

De 30 plantas trazidas para o laboratório, uma delas mostrou-se extremamente tóxica e ao mesmo tempo preenchia todas as condições para explicar o surto da doença. O Alecrim (Holocalyx glaziovii) sendo uma árvore extremamente comum nas matas daquela região, é encontrada profusamente distribuida no pasto, sob a forma de tocos de $1 / 2$ a 1 metro de altura, brotando intensamente (Fig. 14).

O Alecrim sob a forma de extrato aquoso é extremamente tóxico. Os animais morrem $\mathrm{cnm} n \mathrm{~s}$ sintomas de envenenamento pelo ácido cianídrico. 3 a 4 gramas introduzidas por via gástrica em cobáias causam a morte em 10 a 15 minutos. Um bovino de 130 quilos, recebendo por via gástrica 1 quilo da planta sob a forma de extrato aquoso, morreu em menos de 15 minutos. O extrato aquoso tem o cheiro característico das amêndoas amargas. Pequena quantidade de extrato aquecida em tubo de ensaio, desprende ácido cianídrico, o que pode ser evidenciado colocando-se na boca do tubo um pedaço de papel de filtro embebido em ácido pícrico que adquire ao fim de 10 a 15 minutos coloração avermelhada ( $\operatorname{pink}$ ). Se administramos entretanto, até dois terços da dose letal, os sintomas são muito ligeiros. O boi apenas cambaleia, mantendo-se muitas vezes de pé. As vezes cai para se levantar 10 a 15 minutos depois, apresentando um aspecto normal como se nada tivesse acontecido. A repetição dessa dose aparentemente inócua entretanto, conduz a um estado de envenenamento crônico muito semelhante ao apresentado pelos bois na fazenda Guanabara. Numa série de experiências de administração repetida de Alecrim, realizadas na fazenda Mato Dentro em Campinas, pudemos reproduzir com relativa facilidade todos os sintomas da doença: Fenômenos agudos de fotosensibilização como blefaroespasmo, lacrimejamento intenso, panoftalmo e forte polipnéia coincidindo com a exposição do animal ao sól. Iterícia intensa, espessamento da bile até consistência de geléia de morango, degeneração gordurosa do fígado. Finalmente mumificação do couro que se mostra depois quebradiço como casca de árvore sêca, em tudo semelhante ao que observámos na fazenda Guanabara (Figs. 19 e 21). 
Conseguimos reproduzir assim em condições climatéricas mediocremente favoráveis, todas as lesões típicas da doença, bem como os sintomas de fotosensibilização característicos da mesma. Provavelmente isso só se tornou possivel pelo fato da planta conservar a sua toxidez praticamente inalterada e em qualquer época do ano, o que é fundamentalmente diferente do que ocorre com o Tribulus terrestris.

Experiências em curso permitiram já esclarecer o mecanismo de produção dos sintomas da doença crônica, que poderia ser designada de «Peste das queimadas» dada a correlação existente entre o aparecimento da doença e as extensas queimadas de matas virgens na região da Noroeste.

Uma questão de grande importância e que ficou definitivamente resolvida nas experiências realizadas na fazenda Mato Dentro, em Campinas, foi a importância do fator luz solar no desencadeiamento dos sintomas que conduzem à morte dos animais. Um bezerro mantido em estábulo sombrio, durante 31 dias recebeu doses iguais ou mesmo superiores às que receberam outros animais expostos ao sól e que adoeceram ou morreram ao fim de 8 a 22 dias. $\mathrm{O}$ bezerro mantido no estábulo sombrio, nenhum sintoma apresentou digno de nota ao fim daqueles 31 dias de administração diária e intensiva de Alecrim.

Ficou demonstrado assim que os fenômenos de fotosensibilização desencadeiados pelo Holocalyx, são realmente a causa primária de todos os sintomas observados na doença. Aliás êsses sintomas de fotosensibilização, produzidos pela administração do Alecrim são muitas vezes quasi imediatos. Ao fim de 10 a 15 minutos, o animal exposto à luz apresenta fotofobia, pinçando fortemente as pálpebras. Durante a primeira semana, antes de qualquer manifestação extrínseca ou intrínseca (reação de Van den Bergh no sôro sanguíneo) de retenção biliar o animal apresenta sintomas acentuados de fotosensibilização (fotofobia, lacrimejamento intenso, panoftalmo e polipnéia grave). Em um dos animais experimentados, lesões cutâneas já visíveis (queda de pêlo, descamação da barbela) coincidiram com ausência completa de iterícia. Foi mesmo observada ausência de iterícia em animal que apresentou à autópsia formidáveis hemorragias sub-cutâneas localizadas preferencialmente nas regiões da barbela, dorso, axilas e virilhas.

Assim, a iterícia e o espessamento da bile parecem ser uma consequência da ação combinada da planta e da luz e provavelmente da superprodução de pigmentos biliares em consequência das extensas hemorragias sub-cutâneas que desencadeiam na fase pré-terminal do envenenamento crônico pelo Holocalyx glaziovii. 
Realizamos presentemente experiências no sentido de verificar se o ácido cianídrico, administrado sob a forma de cianeto de potássio pode desencadeiar em bovinos sintomas de fotosensibilização. Na primeira experiência realizada já verificámos que, pela administração intensiva de cianeto de potássio, durante 23 dias, um animal exposto ao sól apresentou extensas hemorragias sub-cutâneas, localizadas preferencialmente na barbela, axilas e virilhas. Ora, vimos que essa localização das hemorragias sub-cutâneas é típica da doença na fazenda Guanabara e no envenenamento crônico pelo Alecrim. A experiência citada acima e que foi realizada durante 31 dias em estábulo sombrio, mostra que um bovino pode receber grandes doses de Alecrim (e portanto de ácido cianídrico) sem que se observe nenhum signal de hemorragias sub-cutâneas ou peritoneais, mostrando que aquela ação hemorragica do ácido cianídrico sôbre um animal exposto à luz solar, não pode correr por conta da toxidez primária do cianeto de potássio, mas sim da ação combinada dêste último com a luz solar.

Se o ácido cianídrico fôr mesmo o responsavel pela fotosensibilização produzida pelo Holocalyx, o que será verificado nas experiências em curso, a possibilidade de aplicação dos resultados acima à patologia animal e mesmo humana é consideravel. Outras plantas cianogenéticas poderão então sensibilizar animais à luz e todos sabem a frequência com que ocorre nos nossos campos uma planta cianogenética, a conhecida Mandioca (Manihot utilissima) e outras que serão certamente encontradas por um trabalho sistemático bem orientado. A presença do ácido cianídrico nas folhas da mandioca é um fato conhecido há muito tempo. Recentemente examinámos 14 variedades de mandiocas cultivadas na fazenda Mato Dentro em Campinas. Utilizámos o test referido acima, do papel embebido em solução de ácido pícrico e carbonato de sódio. Todas as variedades ensaiadas deram um test positivo, mais ou menos intenso, revelado por colorações que variaram de ligeiro tom avermelhado a uma forte coloração pink, aparecendo já ao fim de alguns minutos, em banho maria a 100\%. Injetados em cobáias, extratos de folhas de algumas dessas variedades determinaram o aparecimento de sintomas típicos de envenenamento pelo ácido cianídrico.

A fotosensibilização por plantas cianogenéticas não é um fato desconhecido na literatura. Em 1931, HoRWATH descreveu sintomas graves de fotosensibilização em carneiros, pela injestão de uma variedade de Sorghum (Sudan grass). Ora, tem sido referida a presença de ácido cianídrico no Sudan grass (STEYN, 1934) em certas épocas do ano. Certas espécies de trevo (Trifolium) produzem acidentes de foto- 
sensibilização. Ora, em algumas dessas espécies têm sido encontrados glicosides cianogenéticos.

Mas por que mecanismo o ácido cianídrico poderia sensibilizar bovinos à luz?

O efeito do ácido cianídrico foi várias vezes pesquizado na ação fotodinâmica produzida pela combinação de um corante fluorescente e luz. Nós mesmos, em companhia de O. Bier (1934 e 35) estudámos o efeito reforçador do cianeto na hemólise fotodinâmica. Em 1937 estudei o efeito reforçador do ácido cianídrico na oxidação do sôro pela eosina irradiada. Cheguei então à seguinte conclusão: «O sôro fresco de cavalo possue um princípio protetor contra o efeito oxidante da eosina irradiada. Esse princípio termolabil é tornado parcialmente inativo pela adição de ácido cianídrico $\mathrm{m} / 50$ ».

Esse trabalho, realizado naquela época como uma tentativa de aprofundar o mecanismo da ação fotodinâmica, permitirá talvez agora aprofundar o mecanismo da fotosensibilização em bovinos pelo ácido cianídrico. Realmente, os herbívoros possuem em circulação e nos tecidos a filo-eritrina, certamente em doses sub-tóxicas. O papel do ácido cianídrico poderia consistir em baixar o limiar de toxidez da substância, provavelmente inibido aquele princípio protetor a que nos referimos em 1937, a respeito da oxidação do sôro de cavalo pela ação combinada da eosina e luz.

A importância dêsses fatos para a patologia humana, pode apenas ser suspeitada, no momento. E' fora de dúvida que, tambem no homem, frequentemente porfirinas fluorescentes e fotosensibilizantes como a uroporfirina e coproporfirina são encontradas em todos os tecidos e no meio circulante, em doses certamente não tóxicas (KoEnıGsDOERFFER, 1928). Ora êsse fato tem fundas analogias com o que ocorre em herbívoros com a filo-eritrina (porfirina derivada da clorofila). Ora, se em algum momento uma planta fracamente cianogenética passa a constituir parte integrante da alimentação humana, em zonas intensamente insoladas, não é impossivel, em certos casos, o desencadeiamento de fenômenos crônicos de fotosensibilização, com lesões cutâneas localizadas nas partes mais expostas (cabeça e parte superior do tórax). Particularmente uma pesquisa etiológica dirigida nesse sentido, no caso de doentes de "Fogo selvagem» (Pênfigo foliaceo) poderia dar frutos interessantes, dada a forte analogia das lesões cutâneas observadas nesses doentes e as lesões cutâneas que são típicas da ação fotodinâmica observada nos mamíferos. Essa analogia das lesões anatomo-patológicas num e noutro caso, pode ser ressaltada pela comparação das gravuras publicadas recentemente por 
J. P. Vieira (1940) e as publicadas em 1937 por Buengeler, na ação fotodinâmica em camondongos: bolhas, hipertrofias epidérmicas, hiperqueratose, descolamentos epidérmicos e papilomas. O decurso crônico observado no caso do "Fogo selvagem», em que a doença progride, mesmo nos indivíduos trazidos para o hospital, não deve constituir um motivo de abandono daquela hipótese de trabalho, porquanto tambem coelhos sensibilizados e expostos ao sól durante 1 hora $e$ depois trazidos para o laboratório, sem nenhuma nova injeção de corante ou exposiçāo à luz, apresentam uma doença crônica, que se agrava paulatinamente durante mêses! $\mathrm{O}$ aspecto final do animal (ao fim de 2 a 3 mêses), com as suas extensas lesões da pele e distrofía formidavel, de algum modo semelliante ao dos bovinos que receberam cronicamente o Holocaly $x$, torna aquela analogia com o «Fogo selvagem» mais aparente.

Essa sugestão não é feita no sentido de se abandonar a idéia de que o «Fogo selvagem» possa ser uma doença infecciosa, mas visa apenas abrir um novo caminho à pesquisa etiológica da doença. Um fato é indiscutivel: a única doença experimental que se assemelha estreitamente ao nosso «Fogo selvagem» é a doença fotodinâmica desencadeiada em coelhos pela injeção de uma única dose de rose-bengala e uma única exposição à luz solar. A sugestão é feita no sentido de se realizarem pesquisas sistemáticas em tôrno da alimentação dos doentes de "Fogo selvagem», no sentido de se encontrar uma planta cianogenética ou simplesmente fotosensibilizante. Sob êste aspecto tudo que se fizer é novo e poderá abrir novos caminhos.

\section{- aBSTRACT}

1) This paper deals with the importance of the sensitizing effects produced by fluorescent dyes on stock animals and man.

2) A rapid survey of the litterature dealing with the noxious effect produced by the combined action of light and these dyes on small animals and mammalian tissues is done.

3) A special reference is made to the deleterious effects produced by injecting fluorescent dyes on mammals and subsequent exposure to light as an imtroductory study to the effects produced in stock animals by the injestion of plants containing fluorescent photosensitizing pigments.

4) A more extensive approach of some white skin diseases of stock animals as Hypericism, Fagopyrism and Geeldikkop (Tribulosis ovium) is made.

5) A disease of photosensitization in cattle, recently observed and described by us, is presented in a condensed manner. This disease 
definitely associated with the injestion of a cyanogenetic plant «Holocalyx glaziovii» of the leguminous family, presents a bulk of symtoms somewhat similar to those of Geeldikkop. At the first atage the animals present extensive swelling of the skin (Fig. 15) preferentially localized at ears, dewlap and more exposed region of the trunk. Signs of great restlessness and fever are also observed at this stage. Extensive necrosis of the skin occur in the chronic cases, succeeding disappearance of the subcutaneous edemae. The sites of appearance of such scars are also preferential, being almost always the ears, dewlap, outward part of thighs and regions of the belly near axils and groins (Fig. 17 and 18). At the final stage the animals present a miserable appearance lasting for many months and years. The death occurs at the stage of swelling and beginning of skin necrosis. Section shows large subcutaneous haemorrhages localized preferentially at the same sites in which the edemae and scars of the skin occur. Haemorrhages in the peritoneum and walls of the gastrointestinal tract have been also observed, as well as considerable icterus, accompanied by thickening of the bile to consistency and appearance of strawberry jelly. Fat degeneration of the liver with necrosis of the central part of hepatic lobules have been observed microscopically.

Frequently severe lesions in the eyes have been observed (Fig. 16).

The fact the lesions occur preferentially in the most exposed areas and preferentially in the white spots of the skin, conducted ourselves to the diagnostic of photosensitization. With a plant very common it these regions "Holocalyx glaziovii» we reproduced experimentally all the lesions and symptoms of the disease. In this way we have been able to draw a picture of the evolution of the disease. The symptoms of photosensitization (photophobia, abundant secretion of tears, polypnéa and panting) start very soon, during the first week of chronic drenching of extracts of the plant, before any sign of extrinsic or intrinsic (Van den Bergh reaction in the blood serum) icterus. Even after extensive haemorrhages may be detectable by autopsy, no icterus is observed. Icterus, thickening of the bile and severe lesions of the liver, as well as peritoneal haemorrhages and haemorrages of the gastro-intestinal wall, are symptoms of the final stage of the chronic poisoning by «Holocalyx». Finally extensive necrosis of the exposed skin, succeed these subcutaneous haemorrhages and seem to be their immediate consequence. Figs. 19 to 21 show symptoms reproduced experimentally by chronic drenching of "Holocalyx» to calfs. The localization of the subcutaneous haemorrhages and skins lesions reproduced experimentally quite coincide with those observed under natural 
conditions. The final demonstration that the production of all symtoms depends on the combined action of the plant and light has been made by artificially feeding an animal with "Holocalyx» during 31 days in a dark stable without the appearance of any symptom.

6) Some evidence has been presented that HCN itself is responsible for the sensitization to light of animals fed with "Holocalyx glaziovii). Some cases referred to in the litterature, dealing with photosensitizing accidents produced by other cyanogenetic plants (Sudan grass and Clover) may constitute evidences favorable to the above assertion. As a matter of fact we have obtained in a calf which received chronically (23 days) daily toxic doses of KCN, subcutaneous haemorrhages localized at the same sites where appear the lesions in the natural disease and in the chronic poisoning by "Holocalyx».

7) A tentative to explain this ability of HCN to produce photosensitization in herbivorous has been made by assuming that it strengthens the photodynamic action of a naturally occurring porphyrin phylloerythrin - present in the tissues of this animal group.

Experiments on the action of cyanide determining an increase in the photodynamic hemolysis by eosin (BIER \& ROCHA E SILVA, 1935) as well as an increasing in the uptake of $O_{2}$ by sensitized tissues (WoHLgemuth \& SzORENyi, 1933) and sensitized horse serum (ROCHA E SILVA, 1937) have been described in the litterature. This would provide evidences favorable to that tentative explanation of this naturally occurring photosensitization in the cattle produced by a cyanogenetic leguminous plant «Holocalyx glaziovii». Experiments in course will establish this point in a definite manner.

\section{BIBLIOGRAFIA}

Bier, O. \& M. Rocha E SiLva - 1935 - Action du KCN sur l'hemolyse photodynamique. Compt. Rend. Soc. Biol. 118, 911-913.

Blum, H. F. - 1932 - Photodynamic action. Physiol. Rev. 12, 23.

Blum, H. F. - 1933 - Photosensitization. Ann. Int. Med. 6, 877.

Blum, H. F. \& H. J. Templeton - 1937 - Sequel to treatment with photodyn. Journ. of Am. Med. Ass. 108, 548 .

Buengeler, W. - 1937 - Ueber den Einfluss photosensibilisierender Substanzen auf die Entstehung von Hautgeschwuesten. Zeitsch. f. Krebsf. 46, 130.

Buengeler, W. - 1937 - Ueber die Entstehung von Hautcarcinomen und Hautsarkomen nach Sonnenbestrahlung und Photosensibilisierung. Klin. Woch. 16, 1012.

Haussmann, W. \& F. Zaribnicky. - 1929 - Zur Kenntnis des Hypericismus. Klin. Woch. 8, 74.

Haussmann, W. - 1923 - Gruendzuege der Lichtbiologie und Lichtpathologie. Berlin, Wien. Urban \& Schwartzenberg. 
HoRwath, J. A. - 1931 - Sudan Grass as a photosensitizing Agent causing Dermatitis in Sheep (Fagopyrism: White skin disease), N. Amer. Veter., 12, 29.

IONNIDÈs, Z. M. - 1930 - Le pigment phototoxique de l'Hypericum crispum. Compt. Rend. Soc. Biol. 105, 349.

Marsh, C. D. \& A. B. Clawson - 1930 - Toxic effect of St. Johnswort (Hypericum punctatum) on cattle and sheep. U.S. Dep. Agr. Techn. Bull. n. 202.

Meyer-Betz, F. - 1913 - Untersuchungen ueber die biologische (photodynamische) Wirkung des Haematoporphyrins und anderer Derivate des Blutund Gallenstoff. Deut. Arch, f. klin. 112, 476.

Pfeiffer, H. - 1923 - Der Nachweis photodynamischer Wirkungen fluoreszierender Stoffe an lebenden Warmblueter. Abderh. Hbuch. Biol. Arbeitsmeth. VII, 5, 1083.

Quin, J. I. - 1930 - Further investigations into the problem of Geeldikkop (Tribulosis) in small stock. 16th. Rep. Dir. Vet. Serv., 413.

Quin, J. I. - 1933 - Studies on photosensitization of animals in South Africa. I. The action of various Dyestuffs. Onderst. Journ. 1, 459.

Quin, J. I. - 1933. - Studies on photosensitization of animals in South Africa. III. The photodynamic action of Hypericum ethiopicum and Hypericum leucoptychodes. Onderst. Journ. 1, 491.

Quin, J. I. - 1933 - Studies on the photosensitization of animals in South Africa. V. The toxicity of Lippia rehmanni and Lippia pretoriensis. Onderst. Journ. 1, 501.

Quin, J. I. - 1933 - Studies on the photosensitization of animals in South Africa. V. The effect of surgical obstruction of the normal bile flow. Onderst. Journ. 1, 505.

Rimington, C. \& J. I. Quin. - 1934 - Studies on the photosensitization of animals in South Africa. VII. The nature of photosensitizing agent in Geeldikkop. Onderst. Journ. 3, 137.

Rrmington, C., J. I. Quin \& G. C. S. Roets - 1935 - Studies on the photosensitization of animals in South Africa. VIII. The biological formation of Phylloerythrin in the digestive tracts of various domesticated animals. Onderst. Journ. 4, 463.

Rimington, C., J. I. Quin \& G. C. S. Roets - 1937 - Studies upon the photosensitization of animals in South Africa. X. The icterogenic factor in Geeldikkop. Isolation of active principles from Lippia rehmanni. Pears. Onderst. Journ, 9, 225.

Rocha E Silva, M. - 1936 - Contribuição ao conhecimento do mecanismo da acção photodynamica. Rev. Biol. e Hyg. 7, 94-109.

Rocha E Silva, M. - 1937 - Photoxydação do sôro por meio da eosina. Arch. Inst. Biol. 8, 167-182.

Rothemund, P. \& O. Inman. - 1932 - Occurrence of decomposition products of chlorophyll. J. Am. Chem. Soc. 54, 4702.

Sheard, C., H. D. Caylor \& C. Schlotthauer - 1928 - Photosensitization of animals after the ingestion of buckwheat. Journ. of Exp. Med. 47, 1012.

Smetana, H. - 1928 - Studies upon the physiological action of hematoporphyrin. Journ. of Exp. Med. 47, 593. 
Steyn, D. G. - 1934 - The toxicology of plants in South Africa. Onderst. Journ, 3, 359.

Theiller, A. - 1918 - Geeldikkop in sheep. (Tribulosis ovium). 7th and 8th Report Dir. Vet. Res., 3.

Wohlgemuth, J. \& E. Szorenyi - 1933 - Ueber die Wirkung des Lichts auf den Chemismus der Zelle. I. Versuche an Gewebsschnitten. Bioch. Zeitsch. 264, 371-388.

Wohlgemuth, J. \& E. Szorenyı - 1933 - Ueber die Wirkung des Lichts auf den Chemismus der Zelle, II. Versuche an roten Blutkoerperchen Bioch. Zeitsch, 264, 389-405.

\section{EXPLICAÇÃO DAS PRANCHAS \\ Prancha I}

Figs. 1, 2 e 3: Coelho n.o 1 injetado com $0,1 \mathrm{gm}$. de rose-bengala, na veia. Depilado no dorso. Exposto ao sol de 10 horas às 12 horas de 19/7/39. Estadios sucessivos da lesão necrotica da pele.

Fig. 4 - Coelho n.o 2, depilado no dorso. Recebeu $0,12 \mathrm{gm}$. de rose-bengala na veia. Exposto ao sol de 9,30 às 15,45 horas, de $24 / 7 / 39$ Necrose dos lábios e azas do nariz.

Fig. 5 - Coelho n.० 2 Conjuntivite purulenta. Quéda de pelo em torno dos olhos.

Fig. 6 - Mumificação do dorso do coelho n. 2. Alguns dias depois da irradiação.

Fig. 7 - Aspecto miseravel do coelho $\mathrm{n}^{\circ}$ 2, cerca de 20 dias depois da exposição à luz. Mumificação do dorso depilado, extensas quédas de pelo na face. Orelhas mumificadas: cerca de 1 mês depois da exposição à luz, $2 / 3$ do pavilhão das orelhas caíu.

\section{Prancha II}

Fotosensibilização em carneiros injetados com Hematoporfirina

(Segundo Quin, 1931)

Fig. 8- Carneiro com os primeiros sintomas de fotosensibilização, 10 minutos depois da injeção de hematoporfirina

Fig. 9 - Forte edema da face, algumas horas depois da injeção de hematoporfirina.

Fig. 10 - Caso crônico. O carneiro recobrou, desenvolvendo necroses da face.

Fig. 11 - Carneiro Persian Blackhead, injetado com hematoporfirina, Lesões necróticas da pele na parte não pigmentada da pele. A cabeça preta não foi afetada.

\section{Prancha III}

Pasto de 2 anos na Fazenda Guanabara. Em 1938, dezenas de casos foram ai observados

Fig, 12 e 13 - Aspectos do pasto, Vêm-se grandes arvores atingidas pelo fogo das recentes queimadas. Ao nivel do capim podem-se ver troncos de arvores brotando intensamente.

Fig. $14-\mathrm{O}$ Alecrim (Holocalyx glaziovii) como é encontrado brotando no meio do capim. 


\section{Prancha IV}

A peste das queimadas

Fig. 15 - Fase aguda da doença. Forte edema da barbela. Edema das pálpebras.

Fig. 16 - Lesão grave nos olhos. Conjuntivite purulenta com forte lacrimejamento.

Fig. 17 - Caso cronico. Estensas lesōes da pele, formação de escaras.

Fig. 18 - Caso cronico. Lesões necróticas da pele com formação de escaras, em estensa região lateral do tronco.

\section{Prancha V}

Fig. 19 - Panoftalmo e lacrimejamento abundante em consequência da administração de extrato aquoso de Alecrim (durante 5 dias) na Fazenda Guanabara.

Fig. 20 - Mesmo bezerro da fig. 19. Blefaroespasmo com lacrimejamento.

Fig. 21 - Novilha de 130 kilos, aproxim. Recebeu durante 10 dias uma quantidade de Alecrim, sob a forma de extrato aquoso, aproximadamente equivalente a $10 \%$ do seu pêso. No 10.0 dia caíu em prostração em decúbito lateral. Durante 1 semana permaneceu nessa atitude, praticamente em estado de coma, morrendo 17 dias depois do comêço da experiência. No $144^{\circ}$ dia toda a região lateral do tronco mostrava o couro duro e inflexivel (necrose seca). No 16.o dia toda aquela região mostrava-se quebradiça, com o aspecto de casca de arvore sêca, como está representado na figura. A autópsia mostrou intensa icterícia, espessamento da bile até consistência de geléia de morango, degeneração gordurosa do fígado e extensas hemorragias no peritônio e pericárdio. 
M. R. Silva, Fotosensibilização em med. humana e veterinária
Rev. Fac. Med. Vet. S. Paulo, Vol. 1, fase. s-4

Estampa 1
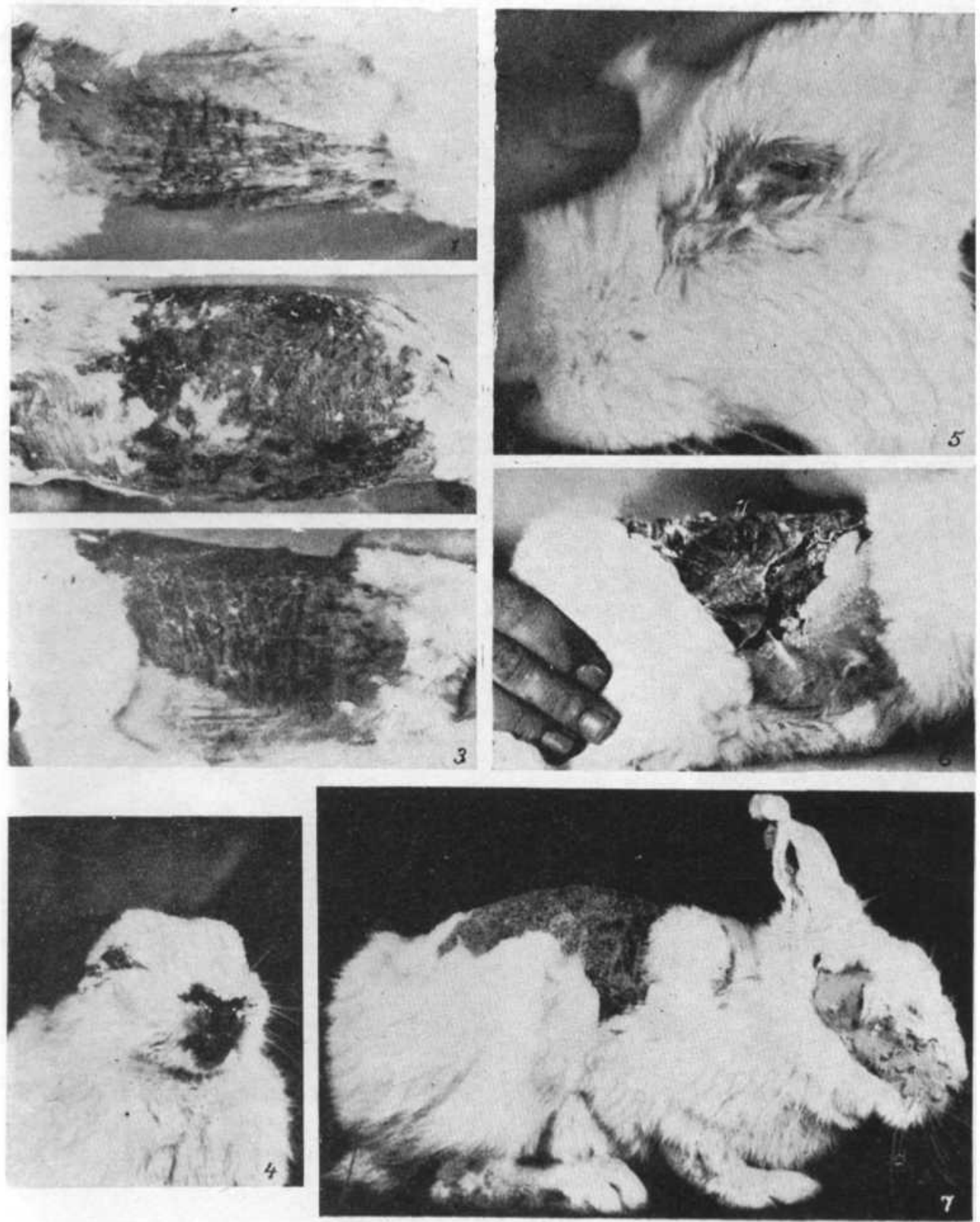
M. R. Silva, Fotosensibilização em med. humana e veterinária
Rev. Fac. Med. Vet. S. Paulo, Vol. 1, fase, s-4

Estampa 2
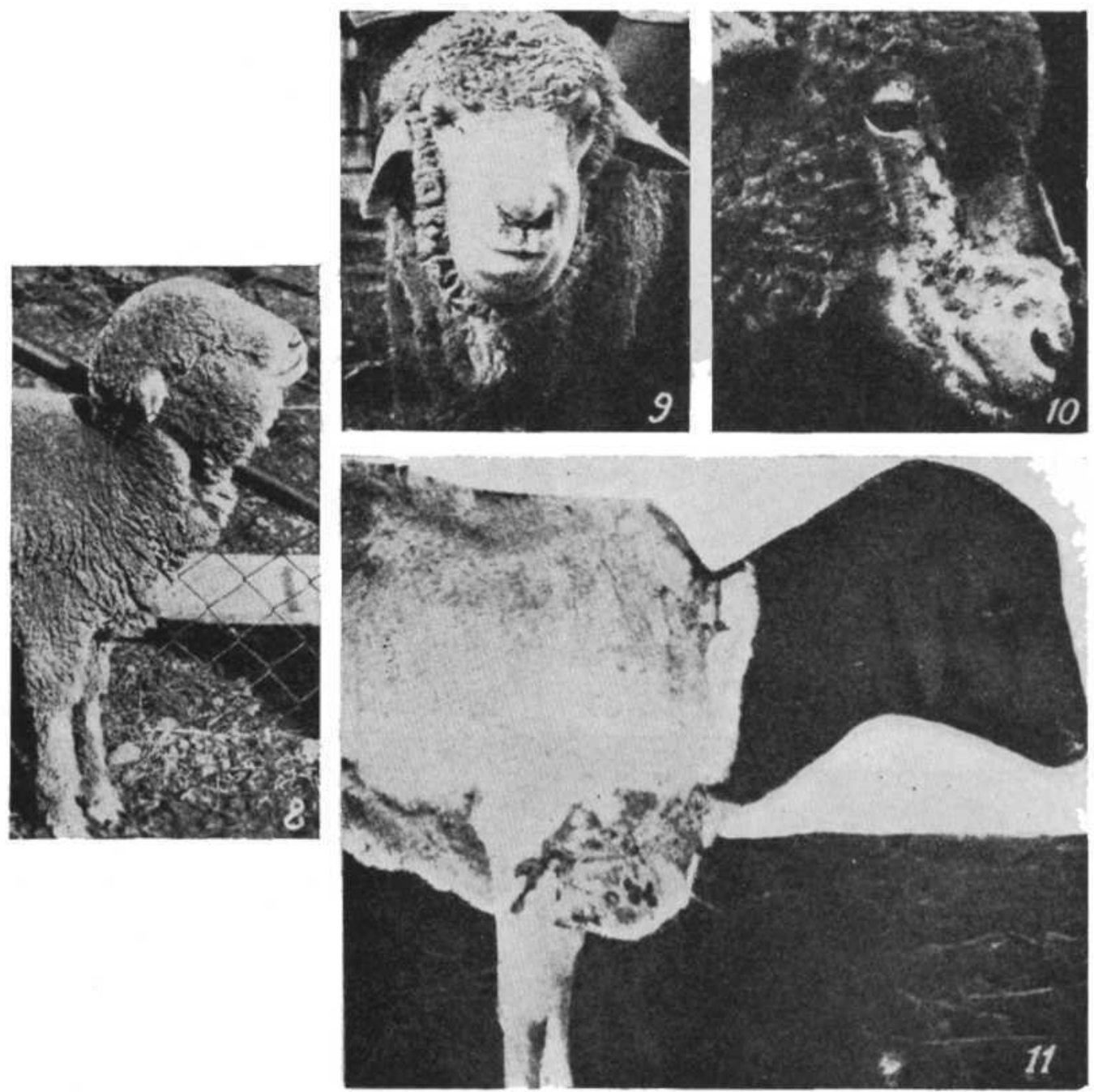
M. R. Silva, Fotosensibilizaçũo em med. humana e veterinária
Rev. Fae. Med. Vet. S. Paulo, Vol. 1, fasc. 3-4

Estampa \&

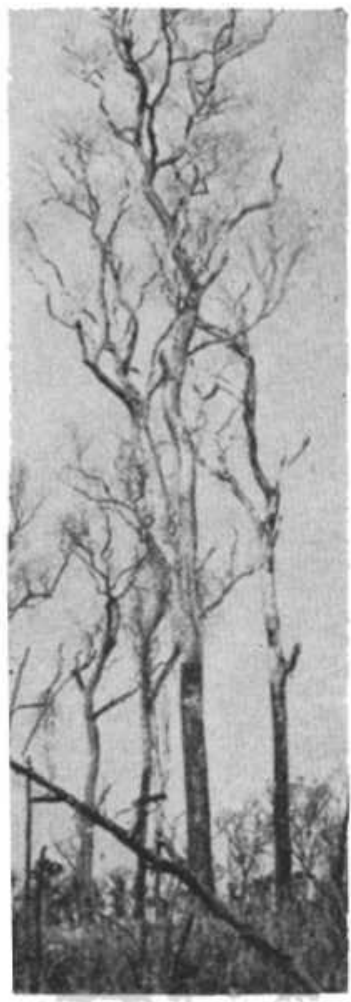

13
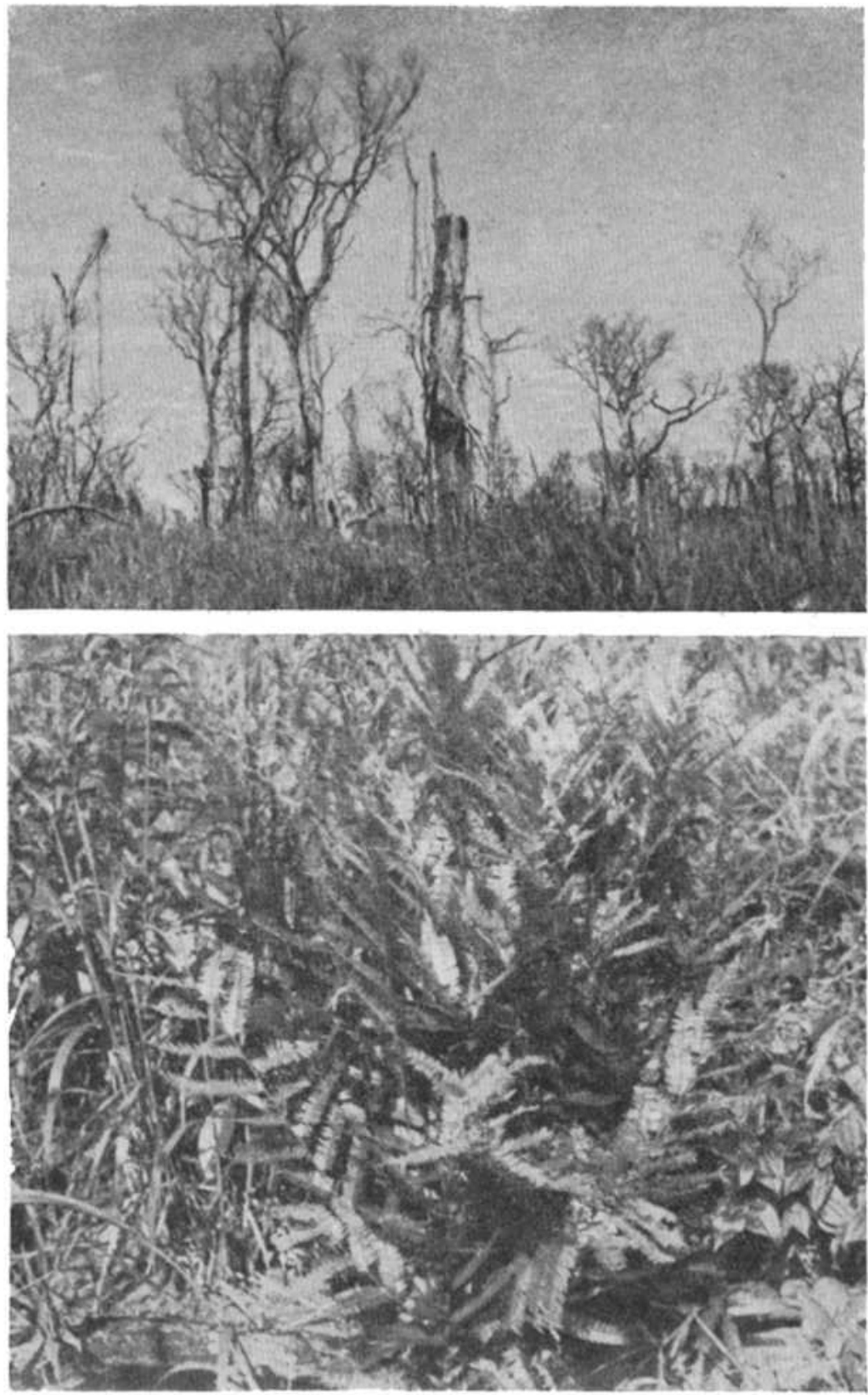
M. R. Silva, Fotosensibilizaçũo em med. humana e veterinária
Rev. Fac. Med, Vet. S. Iaulo, Vol. t, fase. it-4

Estampa \&
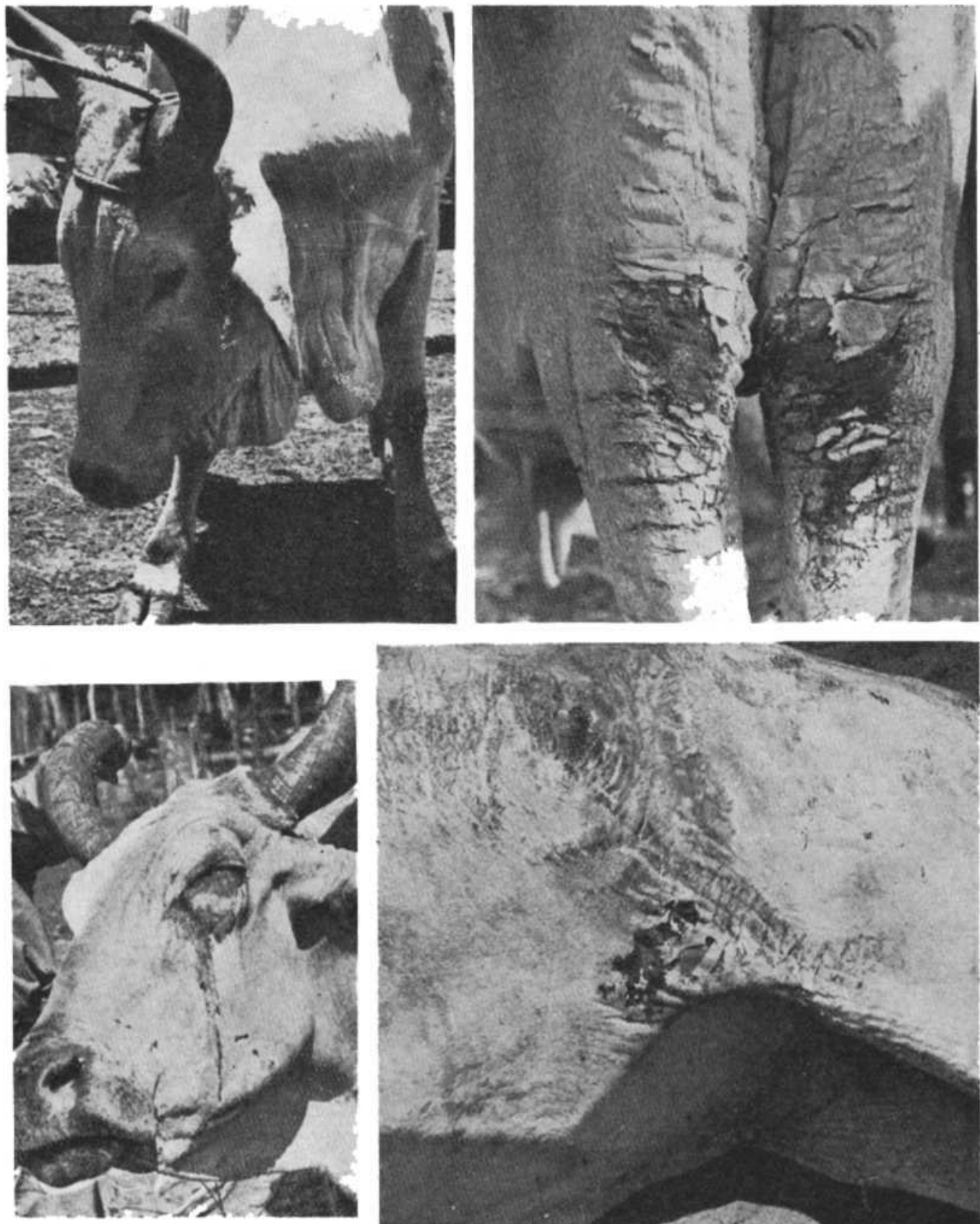

16

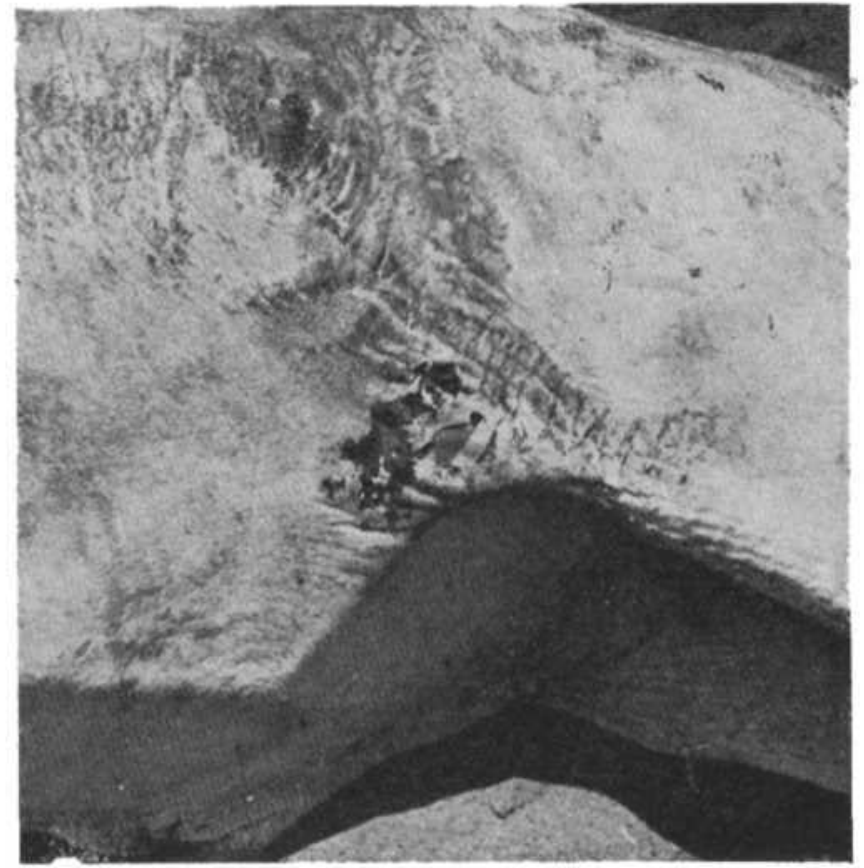


M. R. Silva, Fotosensibilizacão em med, Rev. Fac. Med. Vet. S. Paulo, Vol. 1, fase. 3-4 humana e veterinária

Estampa 5

\section{9}
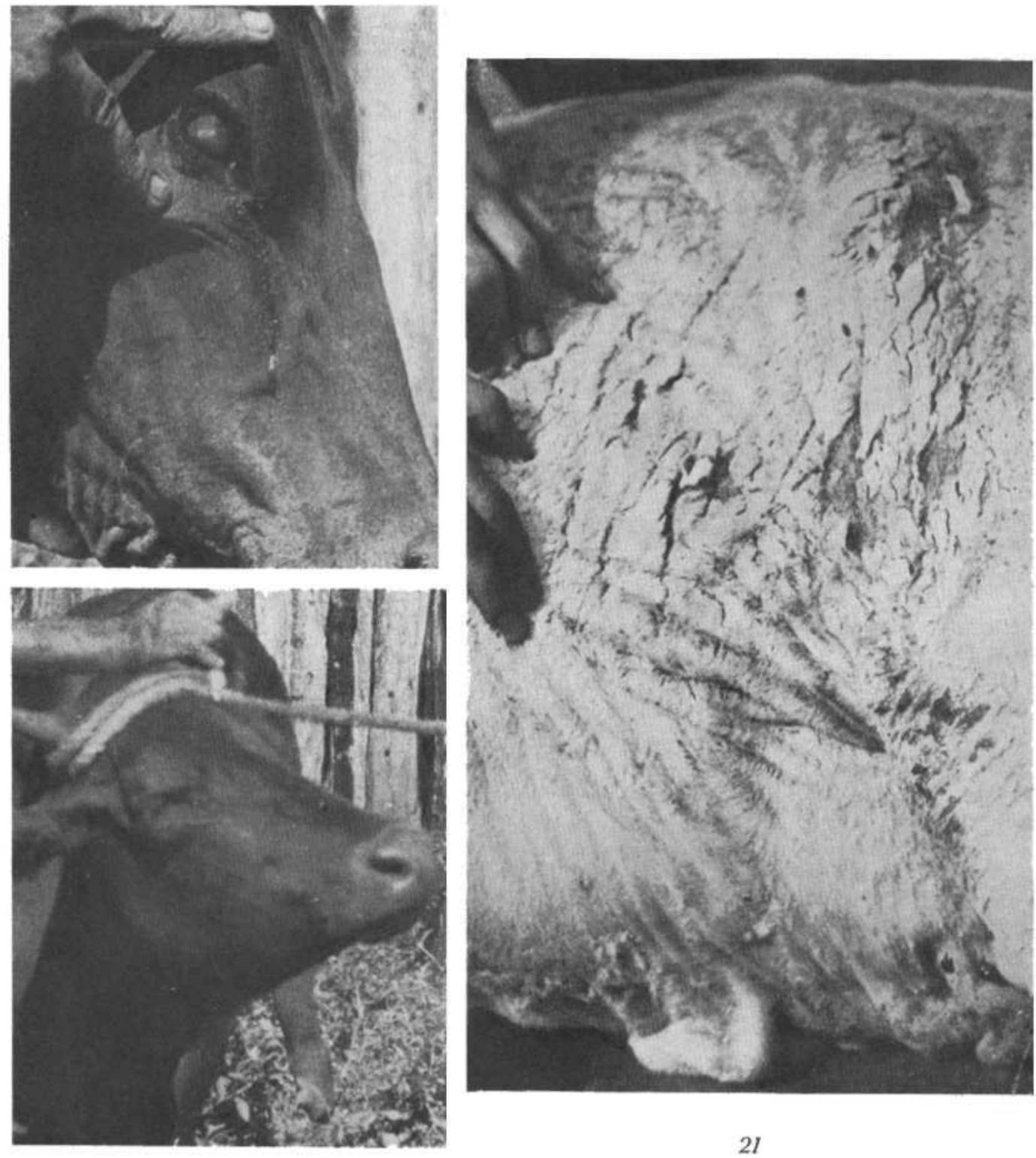